\title{
Microfinance Institutions: Instrumental for Promoting Financial Inclusion
}

http://doi.org/10.21272/fmir.5(2).72-85.2021

Dr. Man Bahadur BK, ORCID: https://orcid.org/0000-0001-8318-9547

Former secretary, Nepal Government, Fulbright Research Scholar, Brandeis University, the USA

Medani P. Bhandari, ORCID: https://orcid.org/0000-0003-2213-2349

Professor, Akamai University, USA, Sumy State University, Ukraine, and Editor in Chief- the Strategic Planning for Energy and the Environment

\begin{abstract}
This opinion paper provides a general overview of microfinance / microcredit which is considered one the major program to minimize the poverty, women empowerment and to socioeconomically inclusive society. There are number of success and failure stories mostly from Africa, Asia, and Latin America; however, the microfinance is global agenda of contemporary world. Based secondary sources, and own experience, the paper provides the general overview of microcredit, its success, the obstacles of microfinance and outlines very brief cases of Nepal and Bangladesh. And finally, paper provides a brief recommendation on how microcredit can be successful especially to the developing world.
\end{abstract}

Keywords: microfinance institutions, financial inclusion, financial inclusion, poverty, empowerment, Africa, Asia, Latin America, Nepal, and Bangladesh.

JEL Classification: D00, D03 and D04.

Cite as: BK, M. B., Bhandari, M.P. (2021). Microfinance Institutions: Instrumental for Promoting Financial Inclusion. Financial Markets, Institutions and Risks, 5(2), 72-85. http://doi.org/10.21272/fmir.5(2).72$\underline{85.2021}$

Received: 3 May, 2021

Accepted: 8 June, 2021

Published: 25 June, 2021

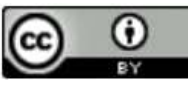

Copyright: (C) 2021 by the authors. Licensee Sumy State University, Ukraine. This article is an open access article distributed under the terms and conditions of the Creative Commons Attribution (CC BY) license (https://creativecommons.org/licenses/by/4.0/)

\section{Introduction}

"Poverty has various manifestations, including lack of income and productive resources sufficient to ensure sustainable livelihoods; hunger and malnutrition; ill health; limited or lack of access to education and other basic services; increased morbidity and mortality from illness; homelessness and inadequate housing; unsafe environments; and social discrimination and exclusion. It is also characterized by a lack of participation in decision making and in civil, social and cultural life." (United Nations-UN World Summit on Social development 1995).

Micro-finance is coined as the financial service rendered to the deprived group of the people and small entrepreneurs to help them in developing self-employment opportunities and various income generating activities. The small size of the loan, regular savings, small-scale entrepreneurs, diversified utilization and simple and flexible terms and conditions are the determining characteristics of its definition. Usually, microfinance is a program that serves a large number of clients with reference to women/deprived people and works at a grassroots level with financial sustainability. The main objective of a micro-finance program is to provide quality service to the largest number of the deprived populace. It aims to attain milestone goal of reducing poverty, tackling marginalization, and reducing inequality traps of poor and deprived section of the society (Sophastienphong and Kulathunga 2009; Todaro and Smith 2003; Tonelli and Dalglish 2012; United Nations 1995; Woller and Woodworth 2001; World Bank 2013; Yunus 1997; Zeller and Meyer 2002; Adams and Pischke 1984; Armendariz 2005; Arp et al 2017; Bateman 2010; Bisen et. al. 2012; Cohen and Nelson 2011; Drake and Rhyne 2002; Duvendack et al 2011; Fuglesang and Chandler 1993; Gibbons 1992; Goetz 1996; Goldberg 2005; Hannig and Jansen 2010; Harper and Vyakarnam 1988; Hulme and Mosley 1996; Johnson 
2009; Johnson and Rogaly 1997; Kabeer 1998; Kadaras and Rhyn 2004; Khandker 1999; Maanen 2004; Mayoux 1998; Morduch and Haley 2002; Mutalima 2006; Rahman 1999; Rhyne 2001; Rooyen 2012; Sharma 2012).

Traditionally, the aim of microfinance is to reach and provide support to sustain and grow to the marginalized, poor, disadvantage group and the women. However, effects of poverty and vulnerability in rural economy has chain of problems- deprivation, lack of entitlements, and opportunities; lack of freedom; lack of demand, low productivity, low quality products, malnutrition; low income, savings and investments, lack of working capital, unemployment (Hearth 2018) and these vulnerable group can even not able to utilize the available resources or be in the social / financial inclusive program. As shown in the text box below the poor vulnerable group remains within the poverty traps because of inequality, lack of choices and opportunities, lack of markets, low growth; myopic behavior, backwardness, lack of information, deprivation; lack of working capital, investment, and production innovations and lack of institutional facilities, incentives by the system, and social network, informal transactions (Hearth 2018:95).

"Critics say that microcredit has not increased incomes, but has driven poor households into a debt trap, in some cases even leading to suicide. They add that the money from loans is often used for durable consumer goods or consumption instead of being used for productive investments, that it fails to empower women, and that it has not improved health or education" (Tonelli and Dalglish 2012).

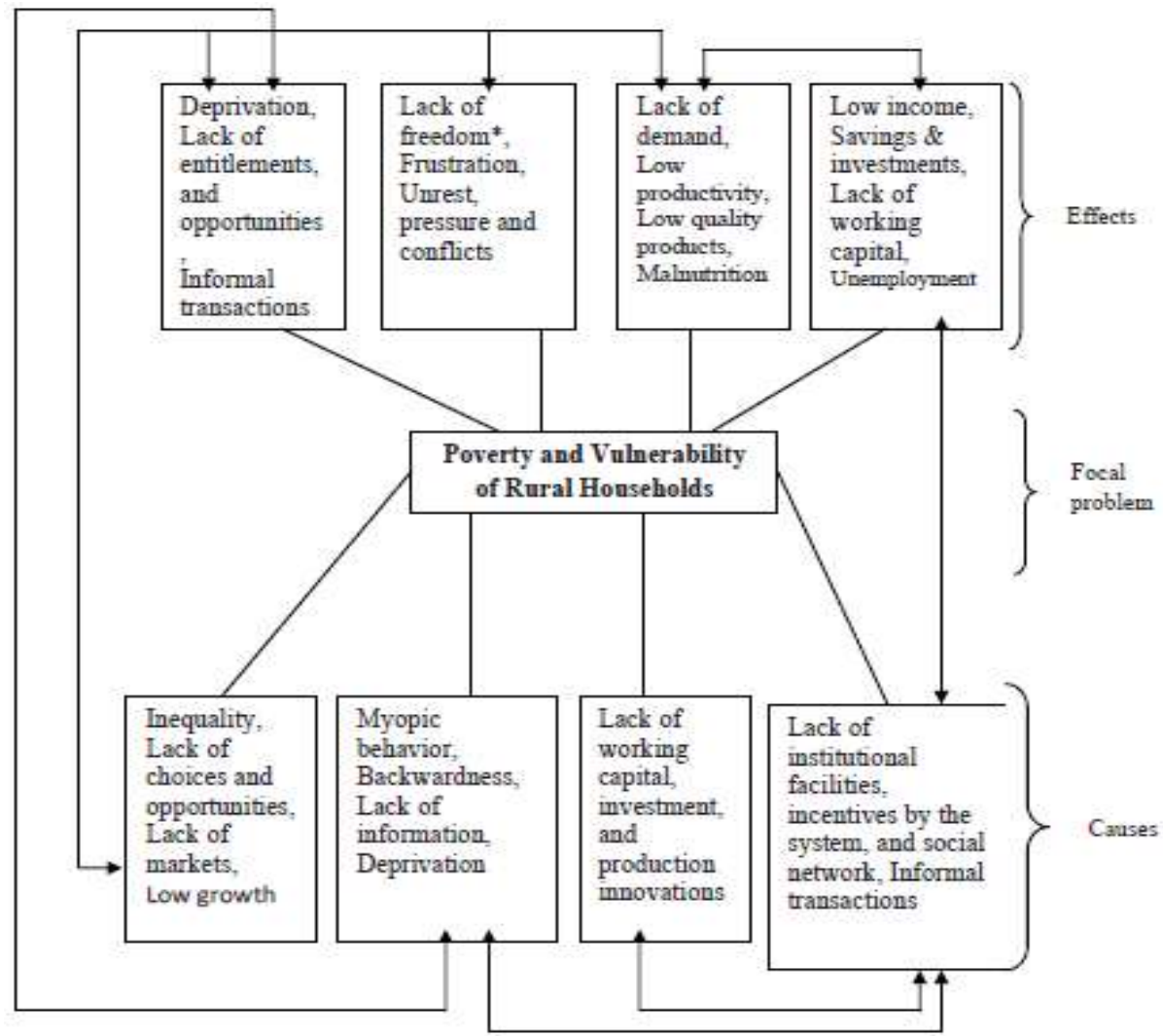

Figure 1. Causes and effects of poverty and vulnerability in rural economy

Source: Sen, (1999); Todaro and Smith, (2003); Hearth, (2018).

* Freedom - political freedoms (in the form of free speech and elections) help to promote economic security. Social opportunities (in the form of education and health facilities) facilitate economic participation. Economic facilities (in the form of opportunities for participation in trade and production) can help to generate personal abundance as well as public resources for social facilities. Freedoms of different kinds can strengthen one another (Sen, 1999). These instrumental freedoms directly enhance the capabilities of people, but they also supplement one another, and can furthermore reinforce one another. These interlinkages are particularly important to seize in considering development policies (Hearth, 2018). In a widespread/severe poverty environment, poor strata of society do not have political, social, and economic freedom, economic opportunities, and economic facilities (Sen, 1999). There is no dynamic internal mechanism in this system to take them to real development path. They are always living as a vulnerable group in the society, but politicians use them when they need votes for the elections. Their economic, social, and political capabilities do not come up under this mechanism. Consequently, capabilities are underutilized by the poor in this unfavorable system as shown in figure (Hearth 2018).

A financial institution is a collection of assets - human, financial, and other - combined to perform activities 
such as granting loans, underwriting insurance, or mobilizing deposits. Projects are not institutions institutions serve a permanent function within the core of a market system. Financial institutions that provide financial services to poor women and men include nongovernmental organization (NGO) microfinance institutions (MFIs), financial cooperatives, formal commercial microfinance banks, specialized MFIs, and other non-bank financial institutions (NBFIs) such as insurance and leasing companies, as well as payment service providers (Ledgerwood, et al, 2013).

\section{Financial Ecosystem}

"Microcredit, or microfinance, is banking the un-bankable, bringing credit, savings and other essential financial services within the reach of millions of people who are too poor to be served by regular banks, in most cases because they are unable to offer sufficient collateral. In general, banks are for people with money, not for people without"(Maanen, 2004), as in (Adhikari and Shrestha, 2013).

The purpose of microfinance is to provide small financial loan support to poor people, which people can begin their own enterprise and earn enough so that they can uplift their livelihood as well as be able to payback the loan amount on time. It tries to reach to the people without money; however, the landing of microcredit follows the almost similar procedure that- the creditors investment needs to be secure. There is no necessary of property collateral, recipients should be organized and ready to follow the rules and regulations of market directed financial ecosystem. The rules of demand and supply as well as trust factors also equally work in the microcredit lending patterns. It is hard to get microcredit support who does not belong to the normal socioeconomic pattern; however, non-profit nongovernmental organization, government and other altruistic organizations can play mediating the role to support to the poorest of the poor by involving disadvantage and marginalized group or individual in the microcredit lending process. As shown in the text box below, the success of microcredit program depends on public willingness to take a risk with the market functionalities.

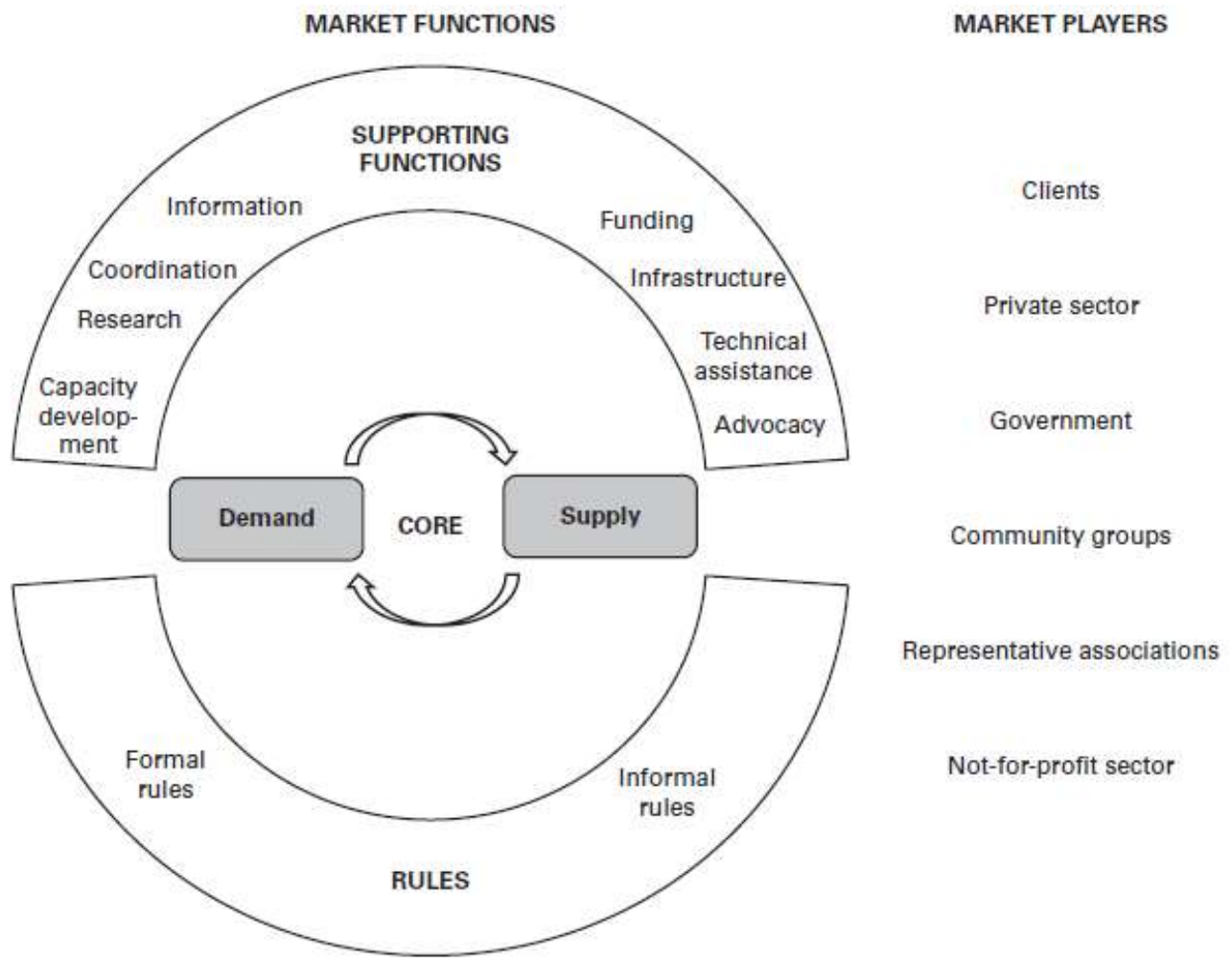

Figure 2. The Cycle of Financial Ecosystem

Source: (Ledgerwood, et al, 2013).

"Core- Transactions between providers and clients (supply and demand); Rules- Informal and formal rules that shape the behavior of market players, including consumers and Supporting functions- The collection of functions that provide information and services supporting the development and expansion of the core.... Understanding financial market systems involves breaking down each of these functions into more detail to identify specific elements within them and the main players who are likely to be directly engaged. Each set of functions can be viewed in isolation, yet in practice functions only have value when seen as integral parts of a wider ecosystem" (Ledgerwood, et al, 2013). 


\section{Coverage of microfinance}

In the contemporary world, the use of microcredit program is common, in developing countries. There are good and bad stories about the impact; however, majority reveals the positive impact to minimize the poverty and to impower women in Africa, Latin America, and South Asia (Seibel, 1997); (World Bank, 2013); (Hearth, 2018); (Samiul, 1993).

"Microfinance is supposed to describe loan offered with no collateral to support income generating business aimed at lifting poor out of poverty". "Poverty is not created by the poor, it is created by the structures of the society, and the policies pursued by the society" (Yunus, 1997).

Microfinance is now seen as an integral part of an inclusive financial system. As a result, financial inclusion has become an important policy goal that complements the traditional pillars of monetary and financial stability, as well as other regulatory objectives such as consumer protection" (Hannig, Jansen, 2010), as in (Ledgerwood, et al, 2013).

Asia is the birthplace of microfinance program, started in Bangladesh and extended to entire continent and the world. "Microfinance is seen as a key development tool, and despite the current deepening crisis within the industry, it continues to grow in sub-Saharan Africa" (Rooyen et.al. 2012:2249). microfinance programs are evolving in Africa and Southeast Asia with the assistance of organizations like, United Nations Development Programme (UNDP) and United Nations Capital Development Fund (UNCDF) IFAD, Opportunity International, Catholic Relief Services, Compassion International, CARE, APMAS, Oxfam, Tearfund and World Vision (NRB 2013; Ledgerwood et al 2013; Hearth 2018). Table 1. Shows gives a brief overview of microfinance reach in six Asian Countries.

Table 1. Microfinance Reach in South Asia

\begin{tabular}{|l|c|c|c|c|c|}
\hline \multicolumn{1}{|c|}{ Country } & $\begin{array}{c}\text { Population } \\
\text { (million) }\end{array}$ & Poverty Ratio \% & $\begin{array}{c}\text { Poor Families } \\
\text { (million) }\end{array}$ & $\begin{array}{c}\text { MF Clients } \\
\text { (million) }\end{array}$ & $\begin{array}{c}\text { MF coverage of } \\
\text { Poor families \% }\end{array}$ \\
\hline Afghanistan & 22 & 55 & 2 & 0.12 & 3 \\
\hline Bangladesh & 143 & $50 *$ & 13 & 16 & 62 \\
\hline India & 1100 & 30 & 60 & 15 & 9 \\
\hline Nepal & 26 & 35 & 1.6 & 0.5 & 14 \\
\hline Pakistan & 155 & 33 & 8.5 & 0.58 & 2 \\
\hline Sri Lanka & 20 & 25 & 1 & 2.5 & 63 \\
\hline
\end{tabular}

Source: (Sophastiernphong and Kulathunga,2009) as in (Hearth, 2018).

In the region roughly, there are about 87 million poor families in six countries and about 35 million have been enjoying microfinance one way or another. Amid the 87 million poor families about $26 \%$ of them are within the microfinance program. Among six countries, Afghanistan has highest poverty ratio 55 percent (one of the cause is conflict and instability), following by Bangladesh, Nepal, Pakistan, and India. As the population and country size Sri Lanka shows the success story, whereas about $63 \%$ poor families are covered by the microfinance program, followed by $62 \%$ Bangladesh. However, in terms of population, country size Bangladesh has been leader in microfinance program (Hearth 2018). This paper just highlights the few examples from Nepal and Bangladesh.

\section{Microcredit program in Nepal}

Nepal has three decades of experience in Micro-finance. Although many programs have been implemented for poverty alleviation, only micro-finance programs are seen as pro-poor and rural based. In Nepal, agriculture-based cooperatives were initiated in the 1950s as a first step in micro-finance (NRB 2013; Adhikari and Shrestha 2013; Sharma 2012; Bhandari 2017). Rural development programs for poverty alleviation were initiated through the Small Farmers Development Programs (SFDP) on a pilot basis in 1975 by ADB/N. On the basis of the success of these programs, the SFDP was transferred into Small Farmers Cooperative Limited (SFCLs), which are managed by the farmers themselves (Sharma 2012). Later, other micro-finance development programs, such as Priority Sector Lending Program (PSLP), Intensive Banking Program (IBP), Production Credit for Rural Women (PCRW) and Rural Self-Reliant Fund (RSRF) were implemented. In 1990, five Regional Grameen Banks were established (NRB 2013) as a replication of the Bangladesh Grameen Bank model of micro-finance delivery. Later on, as a result of the promotion of private sector's participation in microfinance, Nirdhan, CSD, Chhimek and other organizations came into existence NRB 2013; Adhikari and Shrestha 2013; Sharma 2012). Some government's donor-funded directed programs have been implemented in coordination with Nepal Rastra Bank. Lastly, with a new approach, the Community Banking model has been 
promoted in 2010 through a research for substantial financial inclusion (NRB 2013). As the notion, microfinance is for easy and simplified financial access to poor, marginalized, and suppressed groups. The idea has groomed with diversified methods and modalities.

In Nepal 38 percent of the population has the bank account (Kantipur, Jan 31, 2013). It was 26 percent in 2006 with some 28 percent relying solely on informal financial services, and 20 percent were financially excluded (World Bank, 2006) as given in the following figure. As per NRB source there are total 30,036 bank branches of all kinds of banks including microfinance development banks. As per this information it counts 10,800 populations per branch. Besides, there are some 1,187 ATM counters which counts one for 0.1 million population.

Table 2. Microfinance Institutions in Nepal

\begin{tabular}{|l|c|}
\hline \multicolumn{1}{|c|}{ Financial Institutions } & Number \\
\hline Commercial Banks & 32 \\
\hline Development Banks & 90 \\
\hline Finance Companies & 67 \\
\hline Microfinance Development Bank & 27 \\
\hline All Bank Branches & 30,036 \\
\hline Saving and Credit Cooperatives & 11,851 \\
\hline ATM Counters & 1,187 \\
\hline
\end{tabular}

Sources: (Kantipur and Dept of Cooperative Development, 2013).

NRB study also shows that $60 \%$ deposit and $44 \%$ lending are at Kathmandu. The largest provider of the microfinance is non-banking institutions such as Saving and Credit Cooperatives in number of institutions and the clients which counts 24.4 percent of the total clients of microfinance. As per Department of Cooperative there are some 26,501 cooperatives out of which 11,851 (44.72\%) are saving and credit cooperatives throughout the country.

Nepalese micro-finance sector can be classified as formal and semi-formal. Formal sector model is initiated by government/NRB. The initiative so far includes the establishment of Rural Micro-finance Development Center (RMDC) and implementation of the programs as Jagriti (Women Empowerment Program), Bisheshwor with the Poor, IBP, SFDP, and PCRW. The semi-formal model is initiated by NGOs, Cooperatives and local community groups. The widely practiced microfinance models are: Grameen Bank, Village Bank, Swablamban (Self-reliance), and Cooperative. In term of Nepal's legal and regulatory framework, there are two legal options for- i) Community based organization under Cooperative Act 1992 or Social Registration Act 1977 with license to work as financial intermediary under Financial Intermediary Act 1998; and ii) Capital based organization registered as a public company under Bank and Financial Institution Act 2006.

\section{Modalities of Nepalese Micro-finance Sector}

$>\quad$ Grameen banking model (Grameen banking model in Nepal was started in 1992)

$>\quad$ Deprived sector lending model

$>\quad$ Rural Self Reliance Fund (RSRF) model

$>\quad$ Small farmers' cooperatives model

$>\quad$ Financial non-government organizations (FINGOs) model

$>\quad$ Savings and credit cooperatives (SACCOs) model

$>\quad$ Project based micro-credit model

> Wholesale lending model (Nepal Rastra Bank 2013)

The major focus of microcredit program in Nepal is to generating income of the client,

financial sustainability of MFI, enterprises growth/job creation, women empowerment, social improvements, regional/sector development, direct poverty alleviation (Sharma 2012) and to some extend there are some success stories. 


\section{Microcredit Program in Bangladesh}

Bangladesh is the host of success story of microcredit (Duvendack, et. al., 2011); (Goldberg, 2005); (Hearth, 2018); (Ledgerwood, et. al, 2013); (Mazumder and Lu, 2015). In Bangladesh case, "microfinance appears to have reasonably increased recipients' access to basic rights and improved quality of life, as indicated by reduced food insecurity, improved nutrition, food and health, improved clothing, housing, sanitation and drinking water, and better healthcare access and education facilities. The changes were more conspicuous in NGO microfinance recipients than those of GO recipients over the stipulated period of time. The received amount of microfinance in each installment/ cycle, and the recipient's previous experience may also influence respondents' livelihood conditions" (Mazumder and Lu, 2015).

\section{A success story- Microcredit program in Bangladesh}

Bangladesh has a long tradition of volunteerism; however, we do not have exact record how and when volunteer organizations and civil society organizations began for public service delivery. However, the recorded evidence is available since 13 the century, which shows that health, education, and financial assistance to the needy people was Samiul Hasan (1993) notes that because of drought, floods, typhoons, and tornadoes hit Bangladesh on a regular basis, there was a system to help each other to cope with the calamities since people began to stay in this largest delta. Though, those service delivery societies were informal form of social organizations. The history of an organized voluntary organization in Bangladesh, the Baptist Missionary Society, goes back to 1794 . Some other voluntary organizations were subsequently established in 1800,1903 , and 1922 in order to provide medical treatment, education, and spiritual teachings to the rural poor" (page 93). This tendency of volunteer organizations growth was even in the British colonial period (1757-1947) through Pakistani role (1947-1971) to Bangladesh, which continued after the independence in 1971. in practice even before when Muslim invaded Bangladesh in $13^{\text {th }}$ century (Hasan 1992). The origins of microcredit in its current practical incarnation can be linked to several organizations founded in Bangladesh, especially the Grameen Bank. The Grameen Bank, which is generally considered the first modern microcredit institution, was founded in 1983 by Muhammad Yunus (Bateman, 2010).

The tendencies to help each other has never been down and continues. At present, there are thousands of NonGovernmental organizations working in Bangladesh among them the BRAC international is the largest organization in Bangladesh as well as in the world in the context of its reach and programs.

As the public service providing organization, BRAC initiated The Rural Outreach Program and Rural Credit and Training program as an alternative way to fight the poverty, BRAC also lunched the Oral Therapy Extension Program to combat diarrhea in 1979. The Rural outreach and rural credit programs were the kind of exemplary programs of microcredit facility to the rural women of Bangladesh. However, microcredit program has a long history which used to generate and manage by the local and for the local. Formal microcredit program was begun by ACCION International during the 1970 and implemented on trial basis to Brazil, India, and Bangladesh. In India, formally Self-Employed Women's Association (SEWA) established the SEWA Bank with the objective of "strengthening its members' bargaining power to improve income, employment and access to social security" (globalenvision.org 2017). In Bangladesh, formal microcredit program was initiated by Nobel Peace Prize winner, Professor Muhammad Yunus, as an action research program through Chittagong University students in 1976, which spread rapidly to 100s of villages. However, Grameen Bank only founded in 1983, BRAC captured the web length of Professor Muhammad Yunus philosophy about microcredit as a tool to fight against the poverty in Bangladesh, through women empowerment. "BRAC recognized women as the primary caregivers who would ensure the education of their children and the subsequent inter-generational sustainability of their families and households and has thereby been committed to the empowerment of women and education and health of children. Its comprehensive approach combines Microfinance under BRAC's Economic Development program with Health, Education, and other Social Development programs, linking all the programs strategically to counter poverty through livelihood generation and protection. While BRAC believes that micro credit is an important tool in breaking the cycle of poverty, it also places equal emphasis on training its members in income generating activities and facilitating their linkage with consumer markets. Instituting linkages between producers and consumers, BRAC has assisted in the entire process of income generation, juxtaposing itself so as to counter market failures and make it possible for the poor rural producers to be linked to the market for sustainable livelihood" (BRAC 2017). Here it seems that BRAC has been doing social service delivery in the major three sector (1) heath (2) education and (3) social development with the application of market driven approach to combat with poverty in Bangladesh (adopted from Bhandari, 2017). 
As such microcredit program seems successful, however, there are stories of injustice or inhumane behaviors from credit provider organization.

\begin{abstract}
Most of the non-government organizations that disburse micro-credit are pressuring the borrowers to pay back their loans, instead of relief distribution to the flood-affected people. If compared with the total number of the $N G O s$, enlisted with different government bodies, a very small number of them are conducting relief operation in the flood-affected areas. New Age has learnt that the number of the local and the national level NGOs are continuing to press, either directly or indirectly, the flood-hit micro-credit borrowers to pay back their loans. Rahima Begum, a flood victim of Kadamtala in the city, said she had paid her BRAC loan installment during the flood as she felt an indirect pressure to repay loan. "If I fail, I will have to lose my eligibility for receiving any loan in future," she said. Flood victims Renu Begum of Mugda and Nazma Begum of Madinabagh Lane said although they tried their best to remain regular in paying installments of the ASA, they failed for two weeks. "The field officer did not put pressure on me, but I will pay two installments together this week as my failure to repay loans will be considered as non-cooperation," said Renu Begum, who took shelter at Haider Ali High School at East Manda. Meanwhile, the Bangladesh Sangbad Sangstha, a state-owned news agency, reported that the loan officers of the NGOs, including the Bangladesh Rural Development Board, have been moving door to door of the marooned borrowers by boats to realize the installments that have put extra burden on the flood victims. Besides, a number of the NGO field workers, preferring not to be named, said their salaries had been held up for failure to realize the installments of micro-credit. (New Age, August 15, 2004).
\end{abstract}

There are also cases that, the poor people, when they cannot make payments on time to one creditor, they took the loan from another and pay the first one and two pay that they knock the doors of third and so forth, because there is no coordination among the loan providing institutions (NGOs). Each creditor has their own target, and their objective is getting the payment; whatever situation the poor loan holders are facing (flood, family loss, drought, illness, hunger etc.). There is also corruption problem associated with administrative support system (Bhandari 2017). Even such condition, the majority of the poor people are benefited from the competitive microcredit programs and there are noticeable changes in social and economic livelihood of Bangladeshi rural environment.

Similar positive impacts are recorded from other parts of the world (Africa, Latin America and South Asia (Seibel, 1997); (World Bank, 2013); (Hearth, 20180; (Samiul, 1993). Microcredit programs have helped to increase in household income level, acquire, and accumulate more assets than those who don't have access to microfinance, cross over the poverty and overcoming condition of poverty, reducing socioeconomic and political vulnerability and risks, empowerment of women in socially, economically and politically, reduce the isolation and stress of poor, help to extreme poor to find basic needs, savings safety provide the poor with cushion against shocks and risks (Hearth, 2018) and to prepare the marginalized society to raise their voice against the economic and social injustice. Microfinance and other Social Welfare Programs - covers, basic education, basic health care, family planning, nutrition, economic program, water/sanitation HIV/AIDS and shelter (Morduch, and Haley, 2002)

\title{
The Obstacles of Microfinance
}

As illustrated in above text box titled "Causes and effects of poverty and vulnerability in rural economy" it is seriously difficult to overcome from the poverty trap. Therefore, the major obstacle is the extreme poverty, or the cycle of poverty which transfers from generation to generation. The poor are the main victims of all kinds of catastrophic events or incidents (natural disasters, conflicts, wars, pandemic like Covid-19, climate changeraised problems- floods, drought, hurricanes, weather pattern change etc.). In such events women and children are major victim.

In the case of utilization of the beneficial part of microfinance, the poverty trap, keeps the marginalized group beyond the coverage radar because, "their economic, social, and political capabilities do not come up under this mechanism. Consequently, capabilities are underutilized by the poor in this unfavorable (Hearth 2018:94) for any financial uplifting program.

As summarized in (Ledgerwood, et al, 2013), Table 2, women lack the equal rights in financial, economic, social, or cultural, political, or legal systems of the societies, because 'women's legal rights to household assets are not defined in law or useful for collateral; women lack political positions to establish appropriate laws; women lack both traditional and formal legal rights to land'. 
Table 3. Gender-Based Obstacles in Microfinance

\begin{tabular}{|l|l|l|l|}
\hline $\begin{array}{l}\text { Type } \\
\text { obstacle }\end{array}$ & Individual & Household & Wider community or national context \\
\hline Financial & $\begin{array}{l}\text { Women lack access to banks or } \\
\text { financial services in their own } \\
\text { right }\end{array}$ & $\begin{array}{l}\text { Men control cash income and their } \\
\text { expenditure pattern do not } \\
\text { support the household }\end{array}$ & $\begin{array}{l}\text { Men are perceived as controllers of } \\
\text { money and loans }\end{array}$ \\
\hline Economic & $\begin{array}{l}\text { Women undertake } \\
\text { returities that produce low women have a heavy } \\
\text { domestic workload }\end{array}$ & $\begin{array}{l}\text { Households are characterized by } \\
\text { gender division of labor, unequal } \\
\text { access and control of land, labor, } \\
\text { and inputs, and unequal control of } \\
\text { joint household produce and } \\
\text { income streams from this }\end{array}$ & $\begin{array}{l}\text { Women are underpaid for equal work; } \\
\text { anen are locked in low-paid jobs; } \\
\text { stereotypes determine the appropriate } \\
\text { roles for women in the economy; women } \\
\text { lack access to markets for inputs and } \\
\text { outputs if their mobility is constrained due } \\
\text { to social norms }\end{array}$ \\
\hline $\begin{array}{l}\text { Social } \\
\text { cultural }\end{array}$ & $\begin{array}{l}\text { Women are not literate or } \\
\text { educated; girls' education is } \\
\text { not prioritized }\end{array}$ & $\begin{array}{l}\text { Women have a limited role in } \\
\text { household decision making; } \\
\text { polygamy results in conflict, } \\
\text { competition, and discrimination } \\
\text { between wives; violence toward } \\
\text { women is common }\end{array}$ & $\begin{array}{l}\text { Banks and financial institutions do not } \\
\text { view women as a potential } \\
\text { market: women's mobility is constrained } \\
\text { by social norms }\end{array}$ \\
\hline $\begin{array}{l}\text { Political or } \\
\text { legal }\end{array}$ & $\begin{array}{l}\text { Women lack confidence to } \\
\text { claim political and legal rights }\end{array}$ & $\begin{array}{l}\text { Women lack legal rights to jointly } \\
\text { owned household assets }\end{array}$ & $\begin{array}{l}\text { Women's legal rights to household assets } \\
\text { are not defined in law or useful for } \\
\text { collateral; women lack political positions } \\
\text { to establish appropriate laws; women lack } \\
\text { both traditional and formal legal rights to } \\
\text { land }\end{array}$ \\
\hline
\end{tabular}

Source: (Johnson, 2000) as in (Ledgerwood, et al, 2013).

There are some examples that shows that, microfinance program helps women to raise their voices about their rights (Duvendack, et. al., 2011); (Goldberg, 2005); (Hearth, 2018); (Ledgerwood, et. al, 2013); (Mazumder and Lu, 2015); (Bateman, 2010); (BRAC, 2017); (Bhandari, 2017); (World Bank, 2013); (Morduch, and Haley, 2002); and it is repeatedly mentioned that "microfinance programs can increase incomes and lift families out of poverty. Access to microfinance can improve children's nutrition and increase their school enrollment rates, among many other outcomes. Yet it would be imprudent to issue a blanket statement that "microfinance works," for the simple reason that there is no one "microfinance" to test (Goldberg, 2005).

The Table 3, contradict with the above statements, whereas the factual truth is the "households are characterized by gender division of labor, unequal access and control of land, labor, and inputs, and unequal control of joint household produce and income streams, because still, in rural settings "financial institutions do not view women as a potential market: women's mobility is constrained by social norms" (Ledgerwood, et al 2013).

\section{Financial Inclusion: for whom?}

In simple term, financial inclusion to them, who are excluded because of poverty, inequality, no access of education, health, nutritional food, healthy housing as well as discriminated people based on gender, age, origin, ethnicity, disability, sexual orientation, class, and religion. In so far, there are not research about the role of microfinance to empower the people who have been within the poverty traps and who are discriminated on the basis of their identity.

Financial inclusion is a multidimensional, pro-client concept, encompassing increased access, better products, and services, better-informed and-equipped consumers, and effective use of products and services. Putting this concept into practice requires more than institutional expansion and portfolio growth, goals that drove early development of the microfinance industry... Balancing clients' interests and providers' viability, financial inclusion incorporates effective policies, legislation, industry, and consumer protection (Cohen and Nelson, 2011) as in (Ledgerwood et. al., 2013).

The agenda of financial exclusion and inclusion is a global concern which applies to both developing and develop world. The issues of exclusion to the marginalized group in the mainstream process has been a major divisive factor in the society leading towards the inequality. Since last century or so, the world's economic development is accelerating, innovations and automation is in rapid speed, the world is completely connected; however, the inequality is also on rise. The rich are getting richer, and poor are getting poorer. The society is driven through demand and supply chain of market, within the nexus of neoliberal economy; where, marginalized group of people are always left behind. 
In most of the global forums (United Nations, World Bank, IMF, Regional Cooperation Groups etc.) the issue of social inclusion, financial inclusion and equity becomes agenda, and they do policy directives to overcome; however still there is no evidence of the implementation of proposed policy directives. The following is the $\mathrm{G}-20$ principles for financial inclusion.

\section{The G-20 Principles for Financial Inclusion}

At its first summit in June 2010, the G-20 identified a set of principles that reflect conditions conducive to spurring innovation for financial inclusion while protecting financial stability and consumers:

$>\quad$ Leadership. Cultivate a broad-based government commitment to financial inclusion to help to alleviate poverty

$>\quad$ Diversity. Implement policy approaches that promote competition, provide market-based incentives for delivering sustainable financial access, and promote the use of a broad range of affordable services (savings, credit, payments and transfers, insurance) as well as a diversity of service providers

Innovation. Promote technological and institutional innovation as a means to expand financial system access and use, including by addressing infrastructure weaknesses

$>\quad$ Protection. Encourage a comprehensive approach to consumer protection that recognizes the roles of government, providers, and consumers

$>\quad$ Empowerment. Develop financial literacy and financial capability

$>\quad$ Cooperation. Create an institutional environment with clear lines of accountability and coordination within government and encourage partnerships and direct consultation across government, business, and other stakeholders

$>\quad$ Knowledge. Use improved data to make evidence-based policy, measure progress, and consider an incremental "test and learn" approach acceptable to both regulators and service providers

$>\quad$ Proportionality. Build a policy and regulatory framework that is proportionate with the risks and benefits involved in such innovative products and services and based on an understanding of the gaps and barriers in existing regulation

Framework. Consider the following in the regulatory framework, reflecting international standards, national circumstances, and support for a competitive landscape: an appropriate, flexible, risk-based AML/CFT regime; conditions for the use of agents as a customer interface; a clear regulatory regime for electronically stored value; and market-based incentives to achieve the long-term goal of broad interoperability and interconnection. G-20 Information Centre (http://www.g20.utoronto.ca/2010/to-principles.html). As in (Ledgerwood, et al, 2013).

Although the G-20 identified nine major points (leadership, diversity, innovation, protection, empowerment, cooperation, knowledge, proportionality, and framework), for financial inclusive environment cannot be created until or unless there is political commitment.

Financial Exclusion means lack of access to low cost and safe financial services and banking facilities to certain segments of society. It is mainly denial or inaccessibility to basic financial services due to factors like social and economic position, financial literacy, and distance in travelling, hours of operation. The financially excluded sections largely consist of farmers, landless laborer, self-employed, urban slum dwellers, migrants, ethnic minorities, senior citizens, and women. The majority of the people living in rural areas don't have access to financial services. As Indian Institute of Banking and Finance defined financial inclusion is delivery of banking services at an affordable cost to the vast sections of disadvantaged and low-income group. Unrestrained access to public goods and services is the sine qua non of an open and efficient society. As banking services are public good, it is essential that availability of banking and payment services to the entire population without discrimination is the prime objective of the public policy.

Financial inclusion can be said to comprise of ensuring access of financial services and timely, adequate credit to vulnerable groups and giving people an opportunity to build better lives for themselves and their children. It means that people who do not have the access to banking should be provided with that opportunity. It aims at providing appropriate, low-cost, fair and safe financial products and services or instruments, such as bank 
accounts, affordable credit, assets, savings, insurance, payments and remittance facility as well as money advice from mainstream providers to all. It is eventually aimed at providing financial stability to have inclusive growth. Financial inclusion is not only a social compulsion of governments, but an emerging priority for banks that have nowhere else to go to achieve business growth. Implemented right, financial inclusion programs could no doubt offer banks an innovative means of market expansion, customer diversity management and massmarket lifestyle enablement.

Briefly, financial inclusion means financial services to all. The basic foundation of inclusivity is that "poor are bankable". Thus, Prof. Yunus has been advocating for the access to microfinance to be the basic human rights. The MFIs being the social enterprises inclusivity is the major indicator of its performance. Generally, inclusivity can be grouped into two categories: inclusivity by members/clients and inclusivity by product/services (Yunus, 2002, 2003, 1997). While talking about the inclusivity by members, it can be in three stages which show basically the representations and outreach. There are mainly three main layers of the corporate governance system: the governance, management, and beneficiary. First shows the depth of inclusivity in representation which influences the corporate policy formulation. Second generally shows the workforce diversity in staffing which is the main machinery to implement policy in real life business. The third is the way to see how depth and width the clients/members have been connected with the institution and its services. In fact, it is the main foundation of the social enterprises like MFIs. Since microfinance itself is meant for poor, the whole inclusivity has to be observed at its target communities/groups of the society as well as gender perspective.

In term of inclusivity by products/services it is observed how effectively it is designed to attract the deprived communities addressing their needs. Since the state itself has broader ethnic diversity, the MFIs need to consider product diversity in term of ethnic knowledge, skill and occupations. For example, still 42 percent of Dalits are depending on their traditional occupations. Thus, the product/services of the MFIs need to be as diversified as the society is, specially focusing to most unreached people because it is the only option for financial access for them. However, it is very much linked with the dominance in the governance system as mentioned above because product diversity is the matter of policy formulation and its sound implementation. Our most of the products are designed on the agro-based lending which demands landholding. However, there are large number of people without land and running their livelihood with their indigenous/traditional occupations which do not come under microfinance products/services. Neither saving nor lending are that much flexible to build access to most deprived groups of the society. The depth (how much), width (How many) and length (How long) of access in the services creates the financial sustainability to both institutions and the clients/members. Since access is denied by policy, there is no meaning of its depth, width, and length. Product diversification for inclusivity is an innovative approach. However, our MFIs are more in conventional approach. As a result, they are not able to extend its horizon of the access. Neither the government policy is helpful for. So, till now the Microfinance services are reached up to the rural middle class. But it has yet to be reached to the deprived people who do not have any option for financial services.

\section{Conclusion and Recommendations}

Innovative financial inclusion improves access to financial services for poor people through the safe and sound spread of new approaches. The above listed G-20 nine principles (leadership, diversity, innovative, protection, empowerment, cooperation, knowledge, proportionality, and framework) aim to help create an enabling policy and regulatory environment for innovative financial inclusion (Ledgerwood, et al, 2013). The enabling environment will critically determine the speed at which the financial services access gap will close for more than two billion people currently excluded in developing countries. These principles for innovative financial inclusion derive from the experiences and lesions learned for policymakers throughout the world, especially leaders from developing countries. These principles are a reflection of the conditions conducive to spurring innovation for financial inclusion while protecting financial stability and consumers. They are not the rigid set of requirements but are designed to help guide policymakers in the decision-making process. They are flexible enough so they can be adapted to different country context. Therefore, following the nice principles would make microfinance more inclusion friendly and diversity oriented.

Inclusive financial sector development makes two complementary contributions to poverty alleviation; financial sector development is a driver of economic growth which indirectly reduces poverty and inequality traps; and appropriate affordable financial service for poor people can improve their welfare. They are complementary because financial inclusion enables the previously excluded to connect to the formal economy and contribute to economic growth, while economic growth facilitates the inclusion of more people in the 
economy and in the financial system.

Poor people need to able to manage this low, irregular, and unreliable income to ensure regular cash flow and accumulate sufficient amounts to cover lump sum payments. Thus, for poor people money management is an absolutely central part of daily life, perhaps more than for any economic groups. Poor people need a range of appropriate and affordable financial service to address a range of financial needs, such as safe accessible savings, microcredit, payments and transfer services and insurances. So, financial literacy and capability contributes for increasing access in financial services and appropriate use. It also contributes reducing credit pollution. Thus, the government should have campaign for financial literacy and capability to the deprived groups.

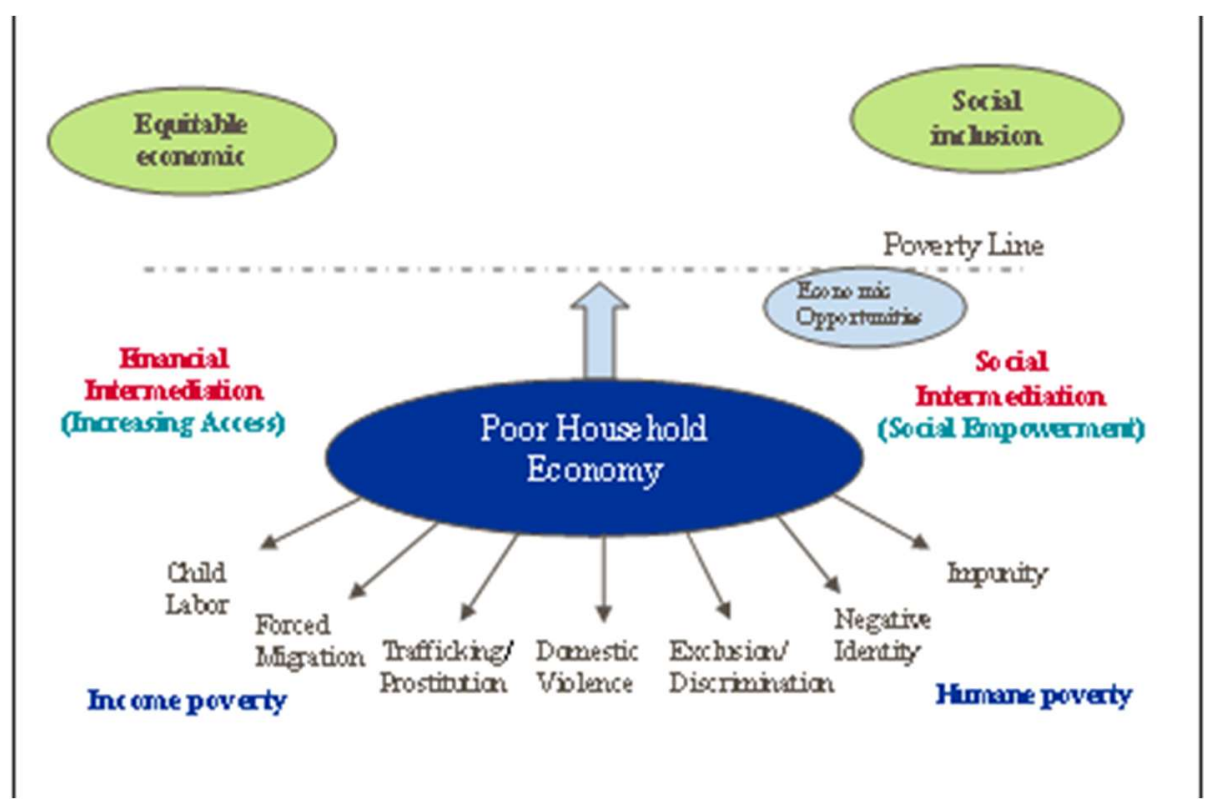

Figure 3. Community Banking Model

Source: (Bk, 2008).

The financial system needs to be restructured so as to make it more inclusive by members/clients and by products/services. "Community banking model" would be an innovative instrument for poverty lending and promoting financial inclusion. The fundamental principle is the socio-humane capability is the best collateral for lending. Providing integrated approach 'credit plus intermediation' on the basis of capability deprivation would bring the most deprived clients/members into financial system. Credit-first individual intervention approach to the most deprived groups would be an effective intervention to attract the most deprived groups. Promoting community capability to have the banking practices themselves at community level and linking it with the formal bank is the basic concept of the community banking model. The approach addresses the income poverty as well as humane poverty of a household and fuels to cross the poverty line in a pivotal way. Thus, it has been recognized as the third-generation microfinance.

Technology is the crucial element of financial inclusion strategy and an enabler of all the others. The choice of technology is therefore a crucial decision, which could make or mar the agenda. Ofthe various selection criteria, cost is perhaps the most important. This certainly does not mean buying the cheapest package, but rather choosing that solution which by scaling transactions to huge volumes reduces per unit operating cost. The government should provide the support to the MFIs to use such technology.

Policy intervention is needed to make wider financial inclusion through state policy on financial inclusion and corporate policy on diversity. It has been envisaged that neither state nor institutional policy is inclusion friendly. There is the need to adopt focused inclusive policy for governance, membership, and service delivery. The joint effort of government, civil societies and other stakeholders for financial inclusion would be crucial. There should be strong legal framework and national policy on building inclusive financial system.

The most important advocacy tool would be- inclusion promotes productivity. Financial inclusion is not only a social compulsion of governments, but an emerging priority for corporate houses to go to achieve business growth. Lessening implementation gap, financial inclusion programs could be an innovative means of market expansion, customer diversity management and mass-market lifestyle enablement. It would be an instrumental 
for inclusive growth for the nation.

(Dr. Bk, is former secretary for Nepal Government, was a Fulbright Research Scholar at Brandeis University, the USA for 2016/17, is the author of the book "Eradicating Hunger: Rebuilding Food Regime", visiting professor and the Advisory Editorial Board Member for the International Journal of Commerce and Management Studies, India.)

\section{References}

1. Adams, D., Graham, D., Pischke, J.D. (1984). Undermining Rural Development with Cheap Credit. Westview Press, Boulder, Colorado. [Google Scholar]

2. Adhikari, D. B., Shrestha, J. (2013). Economic Impact of Microfinance in Nepal: A Case Study of The Manamaiju Village Development Committee, Kathmandu, Economic Journal of Development Issues, 15-16 (1-2). [Google Scholar]

3. Armendariz, B. (2005). The Economics of Microfinance. Cambridge, Mass: The MIT Press. [Google Scholar]

4. Arp, F., Ardisa, A. (2017). Microfinance for poverty alleviation: Do transnational initiatives overlook fundamental questions of competition and intermediation? Transnational Corporations. United Nations Conference on Trade and Development, 24(3), 103-117. [Google Scholar]

5. Bateman, Milford. (2010). Why Doesn't Microfinance Work? The Destructive Rise of Local Neoliberalism'. Zed Books, London

6. Bhandari, M.P. (2017). Role of Nongovernmental Organization in Bangladesh. Are They Challenging the Government Power? A Case Study from Bangladesh Rural Advancement Committee (BRAC), SocioEconomic Challenges, 1(4), 6-23. [Link]

7. Bk, M. B. (2008). Social Inclusion in Microfinance: A Bottom Up Approach, Jana Utthan Pratisthan, Kathmandu, Nepal.

8. Bk, M. B. (2018). Eradicating Hunger:Rebuilding Food Regime, EKTA BOOKS, Kathmandu. [Link]

9. Bisen, A., Dalton, B., Wilson, R. (2012). The Social Construction of the Microfinance Industry: a comparison of donor and recipient perspectives. Cosmopolitan Civil Societies. 4(2), 62-83. [Link]

10. BRAC. (2017). Annul report, BRAC, Dhaka. [Link]

11. Cohen, M., Candace, N. (2011). Financial Literacy: A Step for Clients towards Financial Inclusion. Workshop paper commissioned for the 2011. Global Microcredit Summit, Valladolid, Spain, November 14-17. [Google Scholar]

12. Drake, D., Rhyne, E. (2002). The Commercialization of Microfinance: Balancing Business and Development. Kumarian Press. [Google Scholar]

13. Duvendack, M., Palmer-Jones, R., Copestake, J.G., Hooper, L., Loke, Y., Rao, N. (2011). What is the evidence of the impact of microfinance on the well-being of poor people? London: EPPI-Centre, Social Science Research Unit, Institute of Education, University of London. [Link]

14. Fuglesang, A. Dale, C. (1993). Participation as Process - Process as Growth - What We can Learn from the Grameen Bank. Grameen Trust, Dhaka. [Link]

15. Gibbons, D. (1992). The Grameen Reader. Grameen Bank, Dhaka. [Link]

16. Globalvision, (2017). Microcredit. [Link]

17. Goetz, G. (1996). Who takes the credit? Gender, Power, Control over loan use in Rural credit program in Bangladesh, World Development, 24(1), 45-63. [Google Scholar]

18. Goldberg, N. (2005). Measuring the Impact of Microfinance: Taking Stock of What We Know, Grameen Foundation USA Publication Series, Washington, DC. [Google Scholar]

19. Hannig, A., Jansen, S. (2010). Financial Inclusion and Financial Stability: Current Policy Issues. ADBI Working Paper 259, Asian Development Bank Institute, Tokyo. [Google Scholar]

20. Harper, M. Shailendra, V. (1988). Rural Enterprise: Case Studies from Developing Countries. ITDG Publishing. [Google Scholar] 
21. Hearth, H.M.W.A. (2018). Microfinance Theory and Practice, S. Godage \& Brothers (Pvt) Ltd. 661/665/675, P. de S. Kularatne Mawatha, Colombo 10, Sri Lanka. [Link]

22. Hulme, D., Mosley, P. (1996). Finance Against Poverty. Routledge, London. [Link]

23. Johnson, S. (1997). Gender and Micro-finance: guidelines for best practice. Action Aid-UK.

24. Johnson, S. (2000). Gender Impact Assessment in Microfinance and Microenterprise: Why and How? Development in Practice, 10(1), 89-93. [Google Scholar]

25. Johnson, S. (2009). Quantifying Achievements in Private Sector Development. Centre for Development Studies, University of Bath. [Link]

26. Johnson, S. Rogaly, B. (1997). Microfinance and Poverty Reduction. Oxfam, Oxford UK. [Google Scholar]

27. Kabeer, N. (1998). Money Can’t Buy Me Love? Re-evaluating Gender, Credit and Empowerment in Rural Bangladesh. IDS Discussion Paper 363. [Google Scholar]

28. Kadaras, J., Rhyne, E. (2004). Characteristics of equity investment in microfinance. Accion International. [Link]

29. Khandker, Shahidur, R. (1999). Fighting Poverty with Microcredit. Bangladesh edition, The University Press Ltd, Dhaka. [Link]

30. Kantipur Daily. (2013). Mircrocredit in Nepal, Kantipur Publication, Kathmandu Nepal. [Link]

31. Ledgerwood, J., Earne, J. Candace, N. (2013). The New Microfinance Handbook: A Financial Market System Perspective. Washington, DC: World Bank. [CrossRef]

32. Ledgerwood, Joanna. (1998). Microfinance Handbook. Washington, D.C., World Bank. [Link]

33. Maanen, G. V. (2004). Microcredit: Sound business or development instrument, credit. [Link]

34. Mayoux, L. (1998). Women's Empowerment and Micro-finance programmes: Approaches, Evidence and Ways Forward. The Open University Working Paper, 41. [Google Scholar]

35. Mazumder, M. Shofi, U., Wencong, L. (2015). What Impact Does Microfinance Have on Rural Livelihood? A Comparison of Governmental and Non-Governmental Microfinance Programs in Bangladesh, World Development, 68, 336-354. [Google Scholar]

36. Morduch, J. Haley, B. (2002). Analysis of the Effects of Microfinance on Poverty Reduction. NYU Wagner Working Paper, 1014, 28. [Google Scholar]

37. Mutalima, I. K. (2006). Microfinance and Gender Equality: Are We Getting There? Micro Credit Summit, Halifa, Royal Tropical Institute and Oxfam Novib. [Link]

38. NRB. (2013). Some Glimpses of Micro-Finance Activities in Nepal, Nepal Rastra Bank, Kathmandu. [Link]

39. Rahman, A. (1999). Micro-credit Initiatives for Equitable and Sustainable Development: Who Pays?". World Development, 27(1), 67-82. [Google Scholar]

40. Rhyne, E. (2001). Mainstreaming Microfinance: How Lending to the Poor Began, Grew and Came of Age in Bolivia. Kumarian Press. [Google Scholar]

41. Rooyen, C. V., Stewart, R., Wet, T. D. (2012). The Impact of Microfinance in Sub-Saharan Africa: A Systematic Review of the Evidence, World Development, 40, 11, 2249-2262. [Google Scholar]

42. Samiul, H. (1993). Voluntarism and Rural Development in Bangladesh, Asian Journal of Public Administration, 15, 82-101. [Google Scholar]

43. Seibel, H. D. (1997). Upgrading, Downgrading, Linking, Innovating: Microfinance Development Strategies - A Systems Perspective, Working Paper, Universität zu Köln, Arbeitsstelle für Entwicklungsländerforschung (AEF), Köln.

44. Sen, A. (1999). Development as Freedom, New York, Oxford University Press. [Google Scholar]

45. Sharma S.R. (2012), An Overview of Microfinance Service Practices in Nepal, The Journal of Nepalese Business Studies. [Google Scholar] 
46. Shrestha, S. M. (2009). State of Microfinance in Nepal, Report for Institute of Microfinance (InM) as part of the project on State of Microfinance in SAARC Countries. [Google Scholar]

47. Sophastienphong, K., Kulathunga, A. (2009). Getting Finance in South Asia 2009, The World Bank, Washington DC, 20433.th Street, New York, NY 10107. [Link]

48. Todaro, M. P. Smith S.C. (2003). Economic Development, Eighth Edition, Pearson Education (Singapore) Pte, Ltd., Indian Branch, 482 F.I.E. Patparganj, Delhi 110 092, India. [Link]

49. Tonelli, M. Dalglish, C. (2012). Micro-Credit is Necessary but Not Sufficient for Entrepreneurs in Desperate Poverty, FSR Forum, 14(4), 16-21. [Google Scholar]

50. United Nations. (1995), The Copenhagen Declaration and Programme of Action. World Summit for Social Development, March 6-12, New York, United Nations Department of Publications.

51. Woller, M. G., Woodworth, W. (2001). Microcredit as a Grass-Roots Policy for International Development. Policy Studies Journal, 29(2), 267-282. [CrossRef]

52. World Bank. (2013). The new microfinance handbook: a financial market system perspective / edited by Joanna Ledgerwood, with Julie Earne and Candace Nelson. The World Bank. [Link]

53. World Bank. (2006). Access to Financial Services in Nepal, The World Bank. [Google Scholar]

54. Yunus, M. (2002). Grameen Bank II: Designed to open new possibilities? Grameen Dialogue. Dhaka: Grameen Bank, Mirpur, Bangladesh. [Link]

55. Yunus, M. (2003). Halving poverty by 2015: We can actually make it happen? Dhaka: Grameen Bank , Mirpur, Bangladesh. [Google Scholar]

56. Yunus, M. (1997). Banker to the Poor, Micro-Lending and the Battle Against World Poverty, Public Affairs, 250 West 57th Street, New York, NY 10107. [Link]

57. Zeller, M., Meyer, R. L. (2002). The triangle of microfinance: financial sustainability, outreach, and impact. Baltimore: The Johns Hopkins University Press. [Google Scholar] 